\title{
More Than a Hostile Environment: exploring the impact of the Right to
} Rent part of the Immigration Act 2016

\section{Abstract}

This paper is based on original data from a qualitative study on the impact of the Right to Rent part of the Immigration Act 2016 in Scotland. Our findings show that in addition to being an integral part of the government's project of creating a "hostile environment for immigrants" the process of extending the state's 'law and order' functions to organisations responsible for providing welfare services and distributing public goods is of wider political importance. Here we argue that this process, what Bourdieu calls the rightward tilting of the bureaucratic field, results in widespread discrimination as it entails a shift in focus of its criminalising gaze from 'conduct' to 'status'. The effects of this rightward shift altered the categories through which welfare services were both conceived and delivered more widely. We found that the almost universal opposition of the housing sector to the unwanted imposition of duties previously confined to border control agencies shows the extent to which the state is not a unitary monolith but is, rather, a site of perpetual struggle and contestation. By locating the perspective of housing professionals in relation to the government's attempts to redraw the boundaries of the state's own responsibility, we can gain a valuable insight into the processes of state crafting, which have wider implications beyond merely the creation of a hostile environment for immigrants.

Keywords -Bureaucratic field, Criminalisation, Housing, Immigration, State Crafting.

\section{Introduction}

Based on original research conducted in Scotland, this paper will focus on the extent to which the aims of the Immigration Act 2016, of fostering a hostile environment for immigrants, create both direct and indirect forms of discrimination. By extending the use of Bourdieu's theoretical innovation of the 'bureaucratic field', the argument will be made that the Right to Rent part of the Immigration Act 2016, constitutes an encroachment of the disciplinary and punitive practices of the 'right hand of the state', into what had previously been regarded as the state's welfare function. The housing sector is regarded here as falling loosely under the broad rubric of the state 
since it is comprised of social housing providers that have legally enforceable statutory obligations as well as the private rented sector, which in Scotland, has recently undergone legislative changes that have augmented the rights of tenants and increased the state's regulatory oversight of private landlords. The tensions that arise from both the progressive changes in housing law on one hand and the punitive requirements of the immigration Act on the other emerge from the interview data collected from a range of actors working within the housing sector in Scotland. Before explicating and examining the interview data, this paper will give a brief outline of the Immigration Acts of 2014 and 2016 in order to provide context. It will then locate the issue of immigration within the wider literature. Once the data has been explored, the paper will discuss how Bourdieu's (1998) concept of 'the rightward-tilting of the bureaucratic field' can be further developed to understand how the imposition of border control functions on the housing sector are perceived and resisted. The discussion section that follows will make the argument that the state's attempts to enforce border control functions onto the housing sector risks the emergence of discriminatory practices in the allocation of housing resources. These discriminatory practices in housing act to further compound other forms of discrimination, which not only provide a double regulation of those at the margins of economic and social space, but are intersectional in that they exacerbate the 'ethnic' and 'racial' chaffing caused by the continued rightward tilting of the state's institutions. Beyond the creation of a hostile environment the findings suggest that the effects of the Immigration Act 2016 alter the categories through which welfare services are both conceived and delivered. The explanation that unfurls will show the extent to which the triadic nexus of governance, citizenship and the criminalisation of status converge to redraw the boundaries of the state's responsibility, as well as accounting for the levels of resistance to the imposition of 'new' punitive functions by the housing professionals who are expected to adopt the role of border guards.

In 2016, the Immigration Act was introduced by the then Home Secretary Theresa May to strengthen the prescriptions of the 2014 Act with tougher and more punitive measures aimed at further maintaining a "hostile environment" for illegal immigrants in the UK. Both Acts' powers extend beyond the confines of persons with indeterminate immigration status to include those who might, wittingly or otherwise, assist their ability to remain in the UK by providing them with jobs, bank accounts 
and, of most importance to this study, accommodation. Indeed, the Right to Rent part of the Immigration Act 2016 extends the punitive dimension of the 2014 Act to make it a criminal offence to provide accommodation to anyone who cannot prove that they have permanent or temporary leave to remain in the UK. Although at present, the 2016 Act only applies to England and Wales, the Secretary of State has the power to extend the prescriptions to Scotland in due course. The offence of letting a property to a tenant who does not have adequate leave to remain carries the risk of imprisonment of up to five years (see Crawford, McKee and Leahy 2016, see also Lewis, Waite and Hodgkinson 2017).

The policy reversal which saw the welcoming of Afro-Caribbean immigrants brought to Britain on the Empire Windrush in 1948, followed decades later by their increasing deportation in the period leading up to 2018, has coincided with a steady shift in political direction with regards to immigration policy. The dismantling of the FordistKeynesian compact, a period which saw social security (including the goal of full employment) steadily being replaced by social insecurity since the 1970s (Wacquant 2008, 2009, 2012), has been accompanied by a rightward tilting of the very institutional framework which spawned the welfare state and its various institutions. What has remained constant during this period, we would argue, is the weaponization of anti-immigration rhetoric and the use of anti-immigration policy mechanisms for the generation of negative tropes and the imposition of authoritarian forms of governance including increased levels of surveillance and social control.

This paper will explore the processes through which the state's punitive and paternalistic functions are extended to welfare agencies, as well as providers of essential services such as housing, resulting in what Wacquant $(2008,2009,2012)$ calls the double regulation of marginalised groups, a process in which social assistance is not only conditional but is used as a means of further enforcing the state's policing and surveillance functions on precarious sections of society. This process, we argue, is instrumental in what Bourdieu (1994, 1998, and 2003) calls the rightward tilting of the bureaucratic field, a process that will be explored in more detail below. Firstly, however, it is important to highlight the importance we place upon the findings of our research. In order to do so we will highlight the fact that the Right to Rent part of the immigration Act 2016, which shifts the criminalising gaze from 'conduct' to 'status', acts to influence the practices of housing professionals, by 
forcing them to adopt a border control function. The following section explores the conceptual and empirical gaps in understanding this aspect of governance, locating the issue within existing academic research.

\section{The triadic nexus of governance, citizenship and the criminalisation of status}

To construct a more nuanced understanding of 'functions' of the Immigration Act, it is necessary to locate the issue within the wider literature, as well as in the broader context. In doing this we will uncover the links between the triadic nexus of governance, citizenship, and the criminalisation of 'status'. Once we have located the findings within the literature, we will advance the argument that the Right to Rent proposals are part of a much bigger political project aligned to the transfer of power from the 'nurturing' left-hand to the 'disciplinary' right hand of the state, a process which, among other things, fosters discriminatory practices and increases social division.

A number of researchers have connected the issue of discrimination with the socially constructed notion of 'citizenship' (see Kaufman 2005, Malloch and Stanley 2005, Kaufman and Bosworth in Scott 2013, Bosworth 2012, Bosworth and Guild 2008, Tyler 2013, Malloch and Rigby 2016). Academic literature examining notions of citizenship in the context of foreign nationals and economic migrants has a welldocumented political history. Byrne (2016:2) talks about the 'citizenship turn', a period that saw a national preoccupation with the imposition of citizenship tests, questioning the validity of 'multiculturalism', while advocating a return to integrationist policies. Tyler (2013) locates notions of British Citizenship, in relation to immigration, in the contemporary tenor of citizenship discourse in the 1981 Nationality Act. This, one of the first Acts of the newly elected Thatcher government, had the task of 'state building' through the creation of 'citizenship', which entailed the formation of several categories of British nationality, and which ultimately led to a process that Dixon (1981, quoted in Tyler 2013: 54) described as 'constitutionalising racism'.

This process has many facets. Firstly, Tyler (2013) locates immigration within the wider field of governance, drawing on Foucauldian inspired notions such as 'state racism' and 'hygienic governmentality'. Combining governmentality theory with a psychoanalytical approach, Tyler (2013) broadens the scope of immigration studies, examining the diverse and multifaceted nature of discrimination as well as exploring 
the wider effects of negative tropes surrounding immigration in the UK. Within official discourse exists an undergirding web of binaries, which not only discern the 'deserving' from the 'undeserving' but contribute to political discourse that separates 'citizens' from 'non-citizens', and which (re)defines the numerous oppositions that have given shape to a hierarchy of status (see Balibar 2002, and Guentner et al. 2016). Indeed, since the Blair government of 1997, the raft of legislative changes concerning immigration, asylum, and terror have been characterised by the increased depiction of migrants (including refugees and asylum seekers) as 'suspect communities'. These 'problematic' groups become 'natural' targets for surveillance and intervention, as the weight increasingly shifts from the criminalisation of conduct to the criminalisation of status (Schuster and Majidi 2014, Malloch 2016, Bosworth 2012, Bosworth and Guild 2008). What much, if not most of the academic literature on immigration control portrays, is a system of governance that has not only become increasingly hostile towards immigrants and immigration, but which has become much more authoritarian and punitive, continuously implementing policy innovations that have surveillance, policing, detention and removal at their core.

As will become apparent, the issues that have emerged from the literature around immigration have a great deal of resonance in our interviews with housing professionals in Scotland, which will be explored in detail after an explication of the methods used in obtaining such data.

\section{Research Methods}

Firstly, it is necessary to explain the methods used in collecting the data, but it is also important to highlight the fact that this research was designed as a seed-corn project, with the intention of using the data to inform a much larger funding application focused on in-depth research on the impact of the Immigration Act.

It was the almost universal opposition to the Right to Rent prescriptions among the wider housing sector which stirred our interest in this research. The written submissions in response to the Government's consultation on what was at the time, the Immigration Bill, were largely critical of the proposals to extend the state's immigration function through legally enforceable penalties which compelled landlords and housing providers as well as bank workers, driving instructors, port officials, and 
car rental clerks to become immigration officers by proxy (See Crawford, McKee and Leahy 2016).

A survey by the Residential Landlords Association (RLA) in England found that $82 \%$ of their members opposed the Right to Rent part of the 2014 Immigration Act (RLA 2014). Indeed, the House of Commons Briefing Paper (Bate and Ota 2016: 20) highlights the fact that the Right to Rent was 'controversial' and reported that the majority of landlords who took part in the consultation opposed the plan.

It became clear that such contradictory and agonistic relations between various institutions required further investigation with a view to developing a preliminary research proposal. Our research began with a review of 15 briefing papers and written responses to the Government's consultation on the Immigration Act 2016. We found a number of key themes, which linked almost all of the responses. These revolved around the perceived change to the role of the landlord, the effect on devolved legal competency in Scotland, financial implications for landlords, particularly around the costly issue of evictions, and discrimination. This latter issue is of most importance to this analysis, as it addresses concerns that the Right to Rent would discriminate against groups who already face disproportionate levels of discrimination in the housing sector, as well as having a discriminating effect on marginalised groups who, although not immigrants, are unable to obtain the evidence required to prove that they have leave to remain in the UK.

In-depth semi-structured interviews were carried out with 11 key housing professionals in Scotland. Selection of those interviewed and a schedule of the topics to discuss were guided and informed by the briefing papers and written consultation responses for the Bill immediately before it became the Immigration Act 2016. A relatively small number of interviews were planned with key agencies in the housing field as befit a seed-corn project. With the professional housing sector in Scotland being relatively small, it was easy to identify a number of key players who are influential and whose views could be collated to provide a reasonably balance overview of the main issues arising from the Immigration Act. The housing professionals who had participated in the consultation were approached first, then a small selection of other key players from beyond the landlord sector, who we thought could add insight and a balance of opinion were recruited. Interviewees included four 
participants from social landlord organisations, one social landlord representative group, a local authority umbrella group, a director and a policy officer from two different homelessness charities, a housing worker from a refugee charity, a senior lawyer who acts for landlords in eviction cases, and an employee from a charity that specialises in rural housing issues in Scotland's remote areas and island. The hourlong interviews were designed to explore the main concerns that emerged from the briefing papers and consultation responses, as well as to probe other areas of relevance, which may have not been clearly articulated during the consultation. Participants' accounts have been anonymised and are referred to in the discussion by their job title and organisation. The interview data collected was imported into the qualitative analysis software NVivo 10 and scrutinised for emerging themes. Those related specifically to discrimination are the focus of this paper.

\section{Locating the impact of direct and indirect discrimination of marginalised groups.}

There was unanimity among the interviewees on a number of key points. Firstly, no one interviewed thought that the extension of border control duties to the housing sector was appropriate or indeed necessary. There was consensus that the policing of immigration was beyond the remit of the housing sector, and furthermore it sat in direct opposition to what social landlords saw as their 'role' of fostering community cohesion through the implementation of sustainable housing policies. Secondly, they asserted that the Right to Rent part of the Immigration Act caused confusion in the Scottish context, as it interfered with a strict area of devolved legal competence. Housing in Scotland has been the preserve of the Scottish Parliament at Holyrood since its inception in 1999. The Immigration Act 2016 clearly has the potential to undermine this devolved legal competency as Westminster legislation always takes legal precedence over that passed by any of the devolved Parliaments. Scotland has a comprehensive package of rights, which currently applies to all tenants irrespective of their immigration status or rights to remain in the country. There is no doubt that the Right to Rent legislation has the potential to counteract this. This package of rights, which govern landlord and tenant relations, is a long-founded tenet of the Scottish system. Indeed, the current 40-day notice period prior to eviction proceedings, the need to obtain the decree for eviction in a Sheriff Court, and the requirement to have sheriff officers oversight have their origins in the Housing Act of 
1555 (Stalker 2007). The Immigration Act 2016 prescribes that evictions take place summarily when a person cannot prove their right to remain within the country. This is in complete contrast to not only the spirit of the 1555 Act, but also the spirit of devolved competence, which has seen no fewer than seven Housing Acts passed since the inception of the Scottish Parliament in 1999. The legislative interventions include; the Housing (Scotland) Act 2001, Homelessness Etc., (Scotland) Act 2003, Housing (Scotland) Act 2006, Housing (Scotland) Act 2010, Private Rented Housing (Scotland) Act 2011, Housing (Scotland) Act 2014, and the Private Housing (Tenancies) (Scotland) Act 2016. Arguably, all of these legislative innovations improved housing conditions for, or augmented the rights of, tenants and homeless persons. These two findings will be explored in much greater depth elsewhere.

A pilot of the Right to Rent scheme was carried out in Birmingham in 2015, with the Joint Council for the Welfare of Immigrants (2015) reporting that they had found no fewer than 17 instances of unlawful discrimination during the pilot period. The homelessness charity Crisis (2016) claimed that the unintended consequences of the Right to Rent proposals would involve discrimination of homeless persons as well as women fleeing domestic violence or other such emergency, since they would not readily have documentary proof of status on their person (such as a passport). The Birmingham pilot provided further qualitative evidence of discrimination from a mystery shopping exercise. Some examples of this discriminatory practice are evidenced below, highlighting a lack of adherence to the Home Office's $(2014,2015)$ advice on discrimination:

The landlord said that if I was under that scheme he was not going to bother because he had a local person who wanted the property and it was much easier to rent to them. (Phase 1, Asian shopper, landlord - card advert, telephone)

And:

I was told they needed to look at what they had that was suitable for me and they needed to check with the landlords on whether the landlord wanted to do the Right to Rent check because it cost extra. (Phase 1, Asian shopper, independent agent) (Bate and Ota 2016: 13) 
All the housing professionals in Scotland who participated in the research had some degree of concern for the discriminatory effects of the Act. The interviewees in our study, unanimously claimed that discrimination would affect people who looked and sounded foreign, or who had a foreign sounding name. Some of the interviewees (particularly landlords and charity workers) claimed that the burden of proof was such, that people from marginalised and deprived backgrounds would be unable to prove their residency status. This, they claimed, was problematic because in order to avoid discrimination, by targeting only those who looked or sounded foreign, all tenants would be required to produce evidence of their status.

In order to evidence the extent to which discrimination is an almost universal concern within the housing sector in Scotland and indeed the UK, we will begin with some examples that emerged from the briefing papers and written consultation responses and then move on to examine the interviews themselves. Firstly, the Law Society of Scotland, which raised a number of issues, commented on the fact that they saw discrimination as being a very real possibility.

"We consider that the residential tenancy provisions have the potential to discriminate and to interfere disproportionately with individual rights." (The Law Society of Scotland 2015)

Among the many written submissions to highlight the potential for the Right to Rent provisions to discriminate both directly and indirectly, the following example, from a Scottish homeless charity is pertinent.

Homeless Action Scotland has very strong concerns that the additional 'hassle' and bureaucracy for landlords will mean that if there is a choice between a tenant who is obviously indigenous or someone from a BAME [black, Asian, minority ethnic] group or with a 'foreign sounding' name they will simply choose the easy option, leading to increased direct and indirect discrimination. (Homeless Action Scotland 2015)

The Chartered Institute of Housing $(\mathrm{ClH})$, in their written consultation submission said:

... the potential for discrimination is deeply worrying as is the prospect of the scheme being rolled out before any statement has been issued outlining the 
lessons that have been learned from the pilot and what steps are being taken to improve the system (ClH 2015: 3)

The prescriptions of the Act are perceived to 'encourage' discrimination which, in turn, leads to the propagation of 'racist' attitudes and the corresponding forms of social division that these produce. Racial discrimination, then, becomes something of an unavoidable (and perhaps even unintended) consequence of adhering to the Right to Rent provisions of the Immigration Act. Interviewees articulated this further:

In that meeting I had with the Home Office, the private landlord reps were quite upfront about it. They said "look, if you are a private landlord with one property and you have got the option of someone who looks or sounds foreign, who might be a risk, or someone who looks and sounds and has a name which is obviously indigenous you are going to take the no risk option". Why put yourself through it? And it's not about having a fundamentally racist attitude. (Third Sector Organisation 1)

The above example accords with the findings from the pilot project in Birmingham and is also in alignment with a number of concerns raised by organisations in England. The consensus among interviewees was that the possibility of a five-year prison sentence would have such a prohibitive effect, that people other than those who the Act intended to include, might also suffer indirect discrimination as a result. It was common for interviewees to talk about discrimination because someone's name is foreign, or they don't look 'white'.

With the implementation of the Right to Rent, people may find it harder to get into accommodation. They may well find they face some discrimination, that things get more difficult obtaining accommodation. (Third Sector Organisation 2)

There was little doubt among the interviewees that direct discrimination would be more of an issue than it already is, when the Immigration Act was introduced in Scotland. With respect to the issue of indirect discrimination, many of the interviewees thought that the burden of proof requirements would seriously disadvantage people at the margins of society. 
The following interviewee, from a leading charity in the field, expressed concern about the detrimental effect the Right to Rent would have on British homeless people. The key issue here lies in the perceived difficulties which poorer people would face in trying to prove they have legal right to reside, even if they have never left Scotland. The following example shows that there is awareness of what appears to be 'unintended' consequences of the legislation.

One of our consultation responses was that there is an irony in this, which is that actually, a homeless person from another EU country is far more likely to have an ID card because you are legally obliged to have one in most countries of the EU, than an indigenous UK homeless person. So it might actually be excluding indigenous UK homeless people from access to accommodation and favouring other EU migrants. Now that is not the intention of the legislation, but it is one of these perverse outcomes. (Third Sector Organisation 1).

The burden of proof in status checking protocols also raises concerns for housing professionals. All four interviewees who worked for landlord organisations shared the same disquiet as those highlighted in the examples below, showing concern for the ability of the marginalised to meet the burden of proof requirements.

We need to check people's documentation, so we are checking people's identity. The issue for me is, we can't just do it for somebody whose skin is a different colour or whose name is not Scottish. We have to do it for everybody and to do it for everybody we house. That means people who do not have a passport, who do not have a driving license, who do not have any form of photographic ID. They have maybe had a very chaotic life and they don't have much documentation. Are they going to fall foul? (Housing Association 1).

There was a strong consensus, both in the consultation responses and in the qualitative interview data, that the extension of border control techniques to housing practices, in this case 'status checks', would lead to discriminatory practices, particularly in the private rented sector.

The duty, imposed on social landlords by the Scottish Housing regulator, to apply their policies universally means having to check the status of all tenants. The 
confusion among interviewees, including the lawyer who represented landlord organisations, centred on the issue of what to do with some of the more disadvantaged tenants who could not prove their immigration status but whom the lawyer had thought might be expected to have had the right to remain as they had never left Scotland.

The question is, who's going to do the prosecution? With the greatest of respect, legal firms representing landlords will say 'give us a break'. The Sherriff's going to say, 'you must be joking'. Who in their right mind is going to take a case to court when they know that the tenant simply can't prove they have leave to remain because they don't have a passport or a driving licence but are clearly not an immigrant? (Lawyer who acts for landlord organisations).

The confusion about process was expressed by all interviewees, not just those who manage, or act for those who manage tenancies.

Evidence from the briefing papers and consultation responses, as well as the indepth interview data, suggests that a general consensus exists that places the governance techniques employed in the illegalisation of immigrant groups, and now the criminalisation of landlords who rent to them, at odds with the policy and practice regimes of housing providers. This tension was both explicit and implicit within the data. Of the 11 interviewees, no one thought it was the role of housing to police immigration in the UK. The following excerpt reflects the extent to which housing professionals who work for landlord organisations oppose the very idea of taking on a role, which includes border control duties.

We work so hard to make our services accessible to all. We treat everybody fairly. We don't discriminate against groups. If we start, then, to take on that immigration officer role, that will undermine all of that. "Don't go near them because they will report you to the Home Office". That's awful. (Housing Association 2)

The almost universal concern about 'discrimination' from the housing sector and the unintended consequences of applying the prescriptions of the Act in relation to the Right to Rent, highlights the inherent dangers in extending to one sector, the 
disciplinary remit of another sector, in this case, through the transfer of powers previously held by the UK Border Agency to landlord organisations. This extension of statutory obligations to agencies and organisations that had previously been exempt from the enforcement of border control duties is, it would seem, the principle cause of the discrimination and social division, which arise from the introduction of ever more punitive immigration legislation.

What this legislation does is it off-loads the immigration control duties onto landlords who are ill-equipped to do it effectively. Over $90 \%$ of the refugees that we deal with go through the homeless procedure... So we are becoming more involved in immigration control, having to assert what the person's immigration status is and when their immigration status will be up. We have even seen some housing associations saying we won't allocate to this person because they have temporary immigration status. (Third Sector Organisation 2).

The data clearly shows a sector, a proportion of which comes under the broad rubric of 'the state', at odds with the prescriptions imposed upon it by a government seeking to create a hostile environment for immigrants in the UK.

\section{Rightward Tilting of the Bureaucratic Field}

The rightward tilting of the bureaucratic field is a process which, as highlighted in the interview data above, has enormous relevance to the current situation regarding immigration policy in the UK. This conceptualisation also helps explain a variety of different public and social policy interventions, as well as accounting for recent developments in the practices in 'welfare' provision and the delivery of public services. For Bourdieu (see in particular 1994 and 1998 Bourdieu and Wacquant 1992 as well as Wacquant 2008, 2009, 2012) the bureaucratic field is a key component of the wider field of power, which constitutes the State. In this paradigm, the state is not a unitary monolith of governance, which, headed by a 'ruling class', serves the interests of a specific group. It is, rather, an arena within which various groups, entangled in a network of co-operative competition, struggle for the monopoly over the legitimate right to define issues, such as social problems, the 
solutions to which arise from the process of selecting which problems warrant recognition and which are to be ignored.

Bourdieu's innovative conceptualisation of the bureaucratic field is structured around the notion that the 'left hand' of the state is perceived as the nurturing side, which is responsible for the welfare of its citizens. The 'right hand' of the state is made up of the disciplining institutions, which, by contrast, punishes, polices, controls and incarcerates. Both the left hand and the right hand exist in antagonistic cooperation (since they occupy different positions within the bureaucratic field, and therefore have differently corresponding political outlooks as well as being driven by differently corresponding internal logics). The rightward tilting of the state is what Bourdieu (1994, 1998, 2003) refers to in explaining his observations of the increasing intervention by the disciplining institutions in issues and problems that would have previously received the almost exclusive attention of the left hand of the state, such as welfare and support, social housing, benefits, health and education. The dual effects of both privatisation and increasing levels of 'regulation' and 'inspection' have had a longstanding effect on public services in the UK (see Raco 2013), a fact which has resulted in services being run according to business models while at the same time being much more proactive in promoting policies with surveillance and the modification of behaviour as a principle objective.

Below is a table that highlights the main facets of each category.

[Insert Table 1 here]

Wacquant's (2009) analysis shows that this shift from the left to the right hand of the State, has resulted in the double regulation of those who are at the periphery of the employment sphere, that is, those who are situated in the precarious regions of the lower strata of social space. What is not being suggested here is that the left hand of the bureaucratic Leviathan is an entirely benign force and indeed, Wacquant (2008, 2009) acknowledges the seminal work of Piven and Cloward (1971) in uncovering the ways in which welfare regimes provide the state with additional means by which to regulate marginalised groups. Developing Piven and Cloward's (1971) argument, Wacquant $(2008,2009)$ suggests that the current period of permanent crisis has heralded the introduction of additional disciplinary controls in order to combat the adverse effects of widespread social insecurity. 
The civil tensions and unease created by unemployment and austerity, unfurling through 'disciplinary supervision over the precarious fractions of the post-industrial proletariat' (Wacquant 2009: 307), creates a behaviour changing welfare system, a work-enforcing benefit system, a rent enforcing social housing system, as well as a debt enforcing credit system (see Lazzarato 2013, 2015 for evidence of the latter), all of which are configured to modify behaviours and to foster the surveillance of 'risky' groups. In the context of this study on immigration controls, particularly with regard to housing, this 'rightward' tilting of the State promotes a regime, which in cases such as the implementation of the Right to Rent, prioritises 'status' crimes over crimes of conduct (Malloch 2016). Nowhere is this shift more visible than in the binary forms of categorisation that emerge from the wide range of oppositions, which govern the practices of landlords. These sets of inescapably cognitive and evaluative presuppositions 'paradoxically unite those whom they divide, since agents have to share a common acceptance of them in order to fight over them or through them, and so to produce position takings which are immediately recognised as pertinent and meaningful by the very agents whom they oppose and who are opposed to them' (Wacquant 2005: 100). It is within this governing tension, between the left and right hands of the state, that the binary oppositions, such as those who are either 'deserving or undeserving' of assistance, who are 'citizens or non-citizens', 'genuine or bogus' asylum seekers (see Ahmed 2015 for a more thorough analysis), 'real or fake' victims of trafficking (Malloch 2016) or 'legal or illegal' subjects, are legitimised and in turn prioritised by institutions of the state. What the data from this research shows, is that the binary oppositions and the governing tensions, from which they arise, create the forms of discrimination that constitute the dichotomous positions between the government and the social housing sector in Scotland.

By shifting from a focus on the criminalisation of conduct to the criminalisation of status within immigrant groups, and by enforcing this through a punitive threat of five years in prison for non-compliance, the government succeeds in the modification of behaviour in both immigrant groups and in landlords. As the interview data has shown, this is not something that housing professionals simply accepted without question. The next section will offer a discussion of the sociological principles which help explain some of the governing tensions within and beyond the state.

\section{Discussion - Creating more than a Hostile Environment for Immigrants}


Although increased surveillance of immigrant communities and the steady encroachment of 'everyday borders' (see Leahy, McKee and Crawford 2018 and Crawford, McKee and Leahy 2019) have been augmented by the Immigration Acts of 2014 and 2016, they have been a feature of life for foreign nationals since the Asylum and Immigration Act 1997 that criminalised the employment of persons who have no right to work in the UK. Indeed, as this paper has shown, as well as generating a 'hostile environment', immigration policy has had the effect of altering the categories through which welfare services are conceived and delivered. By forcing landlords to choose between those who may be a risk and those who present little or no risk, the government, operating through state actors, is effectively enforcing its own di-vision of the social world through the imposition of categories for which the landlord or housing professional had previously very little or no interest. The interest is imposed through the need to uphold the law, an act to be performed under the shadow of a five-year prison sentence. Housing professionals are united in their resistance to this sanction, which is of course entirely natural since the threat of imprisonment for something that was previously considered lawful practice would in most professional settings seem at the very least unreasonable. What we wish to argue, however, is that the immediate threat of imprisonment is not how the housing professionals who took part in our research framed the justification for their resistance to the Act. As we have seen, the participants in our research justified their position through the adoption of certain narratives which clearly stand in opposition to the immigration rhetoric underpinning the legislation being imposed. Our data shows that housing professionals actively resist the attempts, by government, to change the frames of reference through which they operate. As Bourdieu (1991, 1996, and 1998) points out, politics is the process through which individuals and groups seek to either conserve or transform the structures of the social world. This is most effectively achieved through the conservation or transformation of the representations of the social world. We argue that this is one of the most pernicious aspects of the Immigration Acts of 2014 and 2016, in that they seek to alter the symbolic order in a way that not only creates a hostile environment for immigrants but alters the very categories through which welfare services are both conceived and delivered. In short, the Immigration Acts serve to reinforce the authoritarian and punitive measures which arise from the rightward tilting of the 
bureaucratic field through redrawing the boundaries of the state's influence upon housing providers and their tenants.

One of the most common sites of confusion over this Bourdieusian inspired approach to understanding the authoritarian turn within modern political discourse is the question of intent (see also Squires and Lea 2013 for a fuller debate). Bourdieu's work in relation to practice (see particularly 1977, 1984, 1990, 1991, $1998,1999,2000)$ rejects conspiracy theories in which powerful groups 'actively' plot the implementation of authoritarian and repressive forms of governance with clear ends in mind. As Wacquant (2013: 252) points out 'all public policies result from a mix of leadership intension, bureaucratic groping, practical trial-and-error and electoral profiteering'. The data presented above illustrates that there are clear tensions between local authorities and social housing landlords on one side and the State, in particular its right hand, on the other. The extent of the fragmentation within the State makes it much more difficult for institutions to 'actively' collude in the realisation of very specific, shared objectives.

The fostering and promotion of discrimination makes no sense from the standpoint of a 'rational choice theory' perspective, which privileges the rational economic thinker over the irrational and compulsive human. Yet forms of direct and indirect discrimination, arising from the implementation of punitive measures, begin to make much more sense when the emotional, cultural and social dimensions of such practices are taken into account (Wacquant 2013). This symbolic aspect is as important as the material conditions that emerge from, and which in turn give rise to, the creation of a range of subjectivities, representations and political tropes, through the uneven distribution of symbolic capital across social space.

In privileging the symbolic dimension of discrimination, the Right to Rent part of the Immigration Act 2016, must be examined within the wider political context. The production and reproduction of negative tropes around the issue of immigration serve a wide range of political functions. Firstly, discrimination serves to create a 'them-and-us' binary that can be mobilised to achieve political objectives. One such function is that it fosters social division in some groups, while uniting others ${ }^{1}$. What

\footnotetext{
${ }^{1}$ This was, we would argue, the case with both the Brexit vote (Dorling 2016, Warren 2016, Virdee and McGeever 2017) and the election of Donald Trump (Giroux 2016).
} 
cannot be ignored is the fact that this is an entirely political process, a process of symbolically making the world through the ability to secure legitimacy in saying what the world is and what should be done about it (Bourdieu 1990, 1991, 1994, 1996, 1998, 2000).

There is, without doubt, an 'economic' underpinning to the symbolic process of immigrant castigation and, as we have argued, these tropes have concrete material consequences for the state and its citizens. If we are to begin to understand the complexity that haunts the ambiguous and indeterminate nature of policies such as the Immigration Act and its Right to Rent element, both the material and the symbolic must be grasped simultaneously. It is important to point out, as Wacquant (2013) does, that law and order rhetoric is not a simple matter of repression, but is, rather more often than not a question of production. As both Bourdieu (1999, 2001, 2003) and Wacquant $(2008,2009,2012,2013)$ have sought to demonstrate, discriminatory policies aimed at demonising groups shorn of economic and cultural capital, as well as having material implications, have enormous symbolic importance. This is evident in their ability to deflect attention away from the everyday predicament of the precariat in times of 'perpetual crises'. What these research findings have shown should discourage a lazy conceptualisation of the State as a unitary monolith or an apparatus (in a crude Althusserian sense). It should instead promote a comprehension of the State as a fragmented and disjointed set of competing institutions, struggling to redraw the boundaries of the symbolic order and thus to turn 'fictions' into reality, a conceptualisation not unlike that developed by the seminal work on the state by Scott (see 1998 for a complimentary analysis of how the state operates).

\section{Conclusion}

The written evidence, highlighted above, show that the majority of landlords in England oppose the Right to Rent, a position that is mirrored in the written consultation responses and briefing papers in Scotland as well as the in-depth interview data from this research. As mentioned in the methods section, this research was designed as a seed-corn project, the intention being that once the Right to Rent was implemented in Scotland, it would be used to inform a much larger bid to conduct research across the country, including the private sector as well as 
other stakeholder organisations. Much more work needs to be done, to better understand the cumulative effects of both extending border control functions to agencies and organisations who do not see this as their role. The gaps that we were unable to fill in this project and which need further exploration include; the views of the private rented sector, the civil servants working at the Scottish Government and members of the black, Asian and minority ethnic community. That said we believe that the evidence presented here in relation to the discriminatory effects of authoritarian forms of governance in the continuing process of 're-regulation' and 'state crafting' provide an important foundation from which to proceed. We would like to conclude with a few assertions which have been drawn from our analysis of the responses of housing professionals to the Right to Rent part of the immigration Act 2016.

Active discrimination through the selective criminalisation of status is part of a political orientation, which arises from the rightward tilting of the bureaucratic state, its ambiguous motives and difficult-to-disentangle effects resulting from the material and symbolic process of what Wacquant $(2008,2009,2012,2013)$ calls 'state crafting'. Thus, the production and reproduction of negative tropes around the issue of immigration serve a wide range of political functions. By promoting negative tropes around the issues of immigration and immigrants, the 'right-hand' of the State is not trying to suppress something that is already there, rather, it is about producing new realities, new categories for 'group making', new discourses and new orthodoxies such as those associated with slogans and legends like 'soft-touch Britain', 'welfare-tourism', 'bogus asylum seekers' and 'creating a hostile environment for immigrants'. Extending Wacquant's analysis of 'crime fighting' to the process of immigration control it becomes apparent that state crafting involves the 'broader redrawing of the perimeter of responsibility of the state operating simultaneously on economic, social welfare and penal fronts' (Wacquant 2013: 255). Thus, through the prioritisation of immigration as a 'social problem', the government, despite evident resistance from some quarters as outlined in this paper, has succeeded in creating more than a hostile environment for immigrants. 


\section{References}

Ahmed, S (2015) The Cultural Politics of Emotion. Edinburgh University Press Ltd: Edinburgh

Balibar E. (2002) Politics and the Other Scene. London: Verso.

Bate A and Ota S (2016) Right to Rent: private landlords' duty to carry out immigration status checks. Briefing Paper Number SN07025, 12 February 2016. House of Commons Library file://C:/Users/jcrawford.JCSHR/Downloads/SN07025\%20(3).pdf

Bosworth M (2012) Subjectivity and Identity in Detention: Punishment and Society in a Global Age. Theoretical Criminology. 16(3): 123 - 140.

Bosworth M and Guild M (2008) Governing Through Migration Control. Security and Citizenship in Britain. British Journal of Criminology.

Bourdieu P (1977) Outline of a Theory of Practice. Cambridge: Cambridge University Press.

Bourdieu P (1984) Distinction. London: Routledge.

Bourdieu P (1990) The Logic of Practice. Cambridge: Polity Press.

Bourdieu P (1991) Language and Symbolic Power. Cambridge: Polity Press.

Bourdieu P (1996) The State Nobility. Cambridge: Polity Press.

Bourdieu P (1998) Practical Reason. On the Theory of Action. Cambridge: Polity

Bourdieu P (1999) On Television and Journalism. New York: The New Press

Bourdieu P (2000) Pascalian Meditations. London: Polity Press.

Bourdieu P and Wacquant L (1992) An Invitation to Reflexive Sociology. London: Polity.

Byrne B (2016) Testing Times: The Place of the Citizenship Test in the UK Immigration Regime and New Citizens' Responses to it. Sociology. 1 - 16

CIH (2015) Right to Rent Consultation Response http://www.cih.org/righttorent

Crawford J, McKee K \& Leahy S (2019) The Right to Rent: active resistance to evolving geographies of state regulation (Forthcoming/Available Online).

International Journal of Urban and Regional Research. https://doi.org/10.1111/14682427.12731

Crawford J, Leahy S \& McKee K (2016) The Immigration Act and the 'Right to Rent': exploring governing tensions within and beyond the state (Policy Commentary).

People, Place and Policy, 10 (2), pp. 114-125. 
Crisis (2016) The unintended consequences of Right to Rent http://blog.crisis.org.uk/the-unintended-consequences-of-right-to-rent/

Giroux H (2016) The Authoritarian Politics of Resentment in Trump's America. Truth-out. http://www.truth-out.org/opinion/item/38351-the-authoritarian-politics-ofresentment-in-trump-s-america (accessed 7th December 2016)

Guentner S., et al. (2016). Bordering practices in the UK welfare system. Critical Social Policy 36(3): 391 - 411

Home Office (2014) Code of Practice for Landlords Avoiding unlawful discrimination when conducting 'right to rent' checks in the private rented residential sector. https://www.gov.uk/government/uploads/system/uploads/attachment data/file/37678 9/Code of Practice for Landlords web .pdf

Home Office (2015) Research Report 83. Evaluation of the Right to Rent scheme Full evaluation report of phase one.

https://www.gov.uk/government/uploads/system/uploads/attachment data/file/46893 4/horr83.pdf

Housing Action Scotland (2015) Immigration Bill 2015 - Housing Measures, Consultation Response Submission.

http://www.homelessactionscotland.org.uk/index.php?page=policy (accessed January 2016)

Joint Council for the Welfare of Immigrants (2015) What's next for the Hostile Environment: The Immigration Act 2016 and the Queen's Speech.

https://www.jcwi.org.uk/blog/2016/05/23/what\%E2\%80\%99s-next-hostileenvironment-immigration-act-2016-and-queen\%E2\%80\%99s-speech (accessed January 2016)

Kaufman E (2005) 'Citizenship, Migration and the Reassertion of National Identity', Citizenship Studies 9(5): 453-67

Law Society of Scotland (2015) Immigration Bill, second reading brief. https://www.lawscot.org.uk/media/644984/imm-immigration-bill-second-readingbriefing-paper-law-society-of-scotland.pdf (accessed January 2016)

Lazzarato, M (2012) The Making of Indebted Man. Chicago: Semiotext(e).

Lazzarato, M (2015) Governing by Debt. Chicago: Semiotext(e)

Lea P and Hallsworth S (2014) in Squires P and Lea J(2014) Criminalisation and Advanced Marginality. Critically Exploring the Work of Loic Wacquant. Bristol: The Polity Press.

Leahy S, McKee K \& Crawford J (2018) Generating Confusion, Concern, and Precarity through the Right to Rent Scheme in Scotland. Antipode, 50 (3), pp. 604620.

Lewis, L, Waite, L and Hodgkinson S (2017) 'Hostile' UK Immigration Policy and Asylum Seekers' Susceptibility to Forced Labour in Entrapping Asylum Seekers Vecchio F and Gerard, A (eds) pp 187-215

Lewis J, Williams A and Franklin B (2008) A Compromised Fourth Estate. Journalism Studies 9:1 1- 20. 
Malloch M. and Stanley E (2005). 'The Detention of Asylum Seekers in the UK: Representing Risk, Managing the Dangerous', Punishment \& Society 7(1): 53-71 Malloch (2016) in Malloch M, and Rigby P (eds) (2016) Human Trafficking: The Complexities of Exploitation. Edinburgh University Press: Edinburgh

RLA (2014) Immigration: Pilot Area Decided http://news.rla.org.uk/immigration-pilotarea-decided/ (accessed 16 September 2016)

Scott, C James (1998) Seeing Like a State: How Certain Schemes to Improve the Human Condition Have Failed. Yale: Connecticut

Scottish Refugee Council (2015) Briefing for Second Reading of the Immigration Bill in House of Commons on 13 October 2015 http://www.scottishrefugeecouncil.org.uk/assets/0001/0207/Briefing for 2nd Readin $g$ of the Immigration Bill - 131015.pdf (accessed 16 January 2016)

Schuster L and Majidi N (2014) Deportation Stigma and Remigration. Journal of Ethnic and Migration Studies, 41(4) 635 - 652

Squires P and Lea J(2014) Criminalisation and Advanced Marginality. Critically Exploring the Work of Loic Wacquant. Bristol: The Polity Press.

Stalker A (2007) Evictions in Scotland. Avisandum: Edinburgh

Tyler I (2013) Revolting Subjects Social Abjection and Resistance in Neoliberal Britain. Zed Books: London

Virdee, S and McGeever, B (2017) Racism, Crisis, Brexit. Ethnic and Racial Studies. DOI: 10.1080/01419870.2017.1361544

Wacquant L. (2008) Urban Outcasts: A Comparative Sociology of Advanced Marginality. Cambridge: Polity.

Wacquant L. (2009) Punishing the Poor: The Neoliberal Government of Social Insecurity. Durham: Duke University Press.

Wacquant, L. (2012) 'Three Steps Towards an Anthropology of Actually Existing Neoliberalism' Social Anthropology, 19 (4) 66 - 79

http://loicwacquant.net/assets/Papers/THREESTEPSHANTHRONEOLIBERALISM.p df

Wacquant $L$ and Akcaoglu A (2017) Practice and symbolic power in Bourdieu: The view from Berkeley. Journal of Classical Sociology 17(1) 55-69

Warren R (2016) Even before Brexit, Theresa May's laws made Britain a hostile place for migrants. The Conversation. http://theconversation.com/even-beforebrexit-theresa-mays-laws-made-britain-a-hostile-place-for-migrants-62467 (accessed 9 October 2016) 